\title{
THE ALBANIAN QUESTION AT THE PARIS PEACE CONFERENCE DURING 1919-1920
}

\author{
Erjon Dervishi \\ Department of History, Albanian Institute of History, Albania \\ ORCID iD: https://orcid.org/0000-0003-0669-320X \\ dervishierjon88@gmail.com
}

\begin{abstract}
This paper aims to bring to the public one of the most important moments in the history of modern times of Albania. After the Albanian independence on 28 November 1912 and international recognition of Albanian state on 29 July 1913, in 1919-1920, many national and international events unraveled which initially posed a real danger for Albania to become an independent state. The Paris Peace Conference, organized after the First World War by the Great Powers which win the war, and in which 27 winning states took part, became the real world center of that time. The Albanian point of view was headed directly at this Conference, with the hope to gain its independence and to win the right of self determination for its people. The main issues of the Conference were: border correction, especially in the southern part of Albania, relations between the Balkan states regarding Albania, the position of Italy, Kingdom of Serbs, Croats and Slovenes, and the position of Greece over Albania, and the real threat of secret pact during the First World War and the new role of American President, Woodrow Wilson. This paper also aims to bring the attitude of the Albanian delegation at the Paris Peace Conference and the position of Italy, France, Great Britain and Greece.
\end{abstract}

Keywords: Albania; France; Italy; Greece; United States; Kingdom of Serbs, Croats and Slovenes, Great Britain; Paris Conference; Delegation

\section{INTRODUCTION}

After Durrës Congress, at the beginning of 1919, the attention of Albanian people was focused on Paris. The Peace Conference started the works here officially on 18 January, organized by the five war winning Big Powers, Great Britain, France, Italy, USA and Japan. As usually, in such cases, the winners would dictate peace conditions to the defeated. In the First World War, Albania did not take side, neither with the winners, nor with the defeated. 
However, it was invaded by several military forces of some winning powers which aimed at violating its territorial integrity, and there was a risk of nullifying the independence achieved in 1913. Meanwhile, Albanian representatives who went to Paris required from the Conference to review the past injustices, hoping that the self-determination principle would be respected. These hopes were grounded in particular on the participation of American representatives headed by President Woodrow Wilson in the conference. The USA was not a signatory to any secret treaties and they pronounced openly that peace would be established not on the basis of such treaties, but by respecting fair principles. In addition, USA formulated then its own attitude for the postwar regulation by stressing that "they would keep the position of arbitrator and they would act according to American justice tradition and magnanimity" (Frus 1919, 47).

\section{THE POSITION OF GREECE}

The Peace Conference did not take into consideration the Albanian delegation demands. Since the beginning, it started to review the claims of Greek government submitted in writing and orally by E. Venizelos. The government of Athens required the annexation of Korçë and Gjirokastër (Clogg 2004, 43). The Greek Prime Minister appeared before the Conference with the invented and no old-fashioned thesis according to which the Christian (Orthodox) Albanians that comprised half of the inhabitants of these regions felt themselves as Greeks. E. Venizelos referred also to London Treaty of April 1915, which charged Italy not to oppose the annexation of southern Albania by Greece if this should be required by other Treaty signatories, Great Britain and France (the fourth signatory, the tsarist government of Russia, toppled over by October revolution did not take part in the Conference) and if Italy would take for itself what this Treaty provided for. For this reason, the Greek government representative did not pronounce against the claims of Italy for Albania, but for the division of Albania with the neighbor across the Adriatic.

\section{THE POSITION OF SERBIA}

Another attitude was held by representatives of Kingdom of Serbs, Croats and Slovenes or Yugoslavia (It was renamed as Yugoslavia in 1929 after the 9 January dictatorship, at the point of the Paris Peace Conference it was still the Kingdom of SCS), which did not express any territorial demands toward Albania directly. The Kingdom of Serbs, Croats and Slovenes delegation pronounced for the independence of Albania in the borders of 1913. This diplomatic attitude was determined by the strong Italian-Kingdom of Serbs, Croats and Slovenes rivalry in the Adriatic and in Albania. The Belgrade government was willing to have in its south-western borders a small Albanian independent State rather than an aggressive neighbor as Italy on Albanian land, which would urge the destabilization and dissolution of the multinational Kingdom of Serbs, Croats and Slovenes state. 
On the other hand, Kingdom of Serbs, Croats and Slovenes government was thinking to place Albania under its political influence through E. Toptani, by supporting his ambitions to come to the head of Albanian government and state (Fischer 2204, 34).

Meanwhile, Belgrade diplomacy connected its attitude towards Albania with that of the two other neighboring states. The Kingdom of Serbs, Croats and Slovenes Memorandum submitted to the Conference in February 1919 stated that if the right of invasion to protectorate in some parts or the entire Albania of 1913 would be recognized for some other country, then, for 'protection of its vital interests', Kingdom of Serbs, Croats and Slovenes reserves the right to require the part that 'belonged to it'. This double attitude of Belgrade would continue throughout the Peace Conference and it aimed at achieving two goals: a) to separate the conflict between Rome and Belgrade for land division between the former Austro-Hungarian Empire, for which both parties had claims, from that of the division of Albania, as foreseen in its Treaty of April 1915; b) to place Kingdom of Serbs, Croats and Slovenes in the same footing with Greece and especially with Italy for Albanian State division and not allow them to exclude it from this division as Italian diplomacy was trying to do so. So the previous Austrian-Italian rivalry for Albania was replaced by the Italian-Kingdom of Serbs, Croats and Slovenes antagonism (Fischer 2004, 45).

\section{THE POSITION OF ITALY}

On its part, the Italian government aimed at ensuring first of all the possession of Vlora, as an important geostrategic point in the Southern Adriatic and putting over the Italian protectorate the "Albanian autonomous state", that was foreseen to be established on the "Muslim" Middle Albania (Montanelli 2005, 12). Also Rome demanded that this protectorate or control should be extended possibly to the borders of Albanian of 1913. Italian delegation neither did nor presents these claims immediately to the Conference, as the Greek delegation did. Italy did not make this immediately because it was listed among the winning Big Powers that has organized the Conference and gave themselves some special rights compared to other smaller winning countries. In addition to this, there were contradictions for the future of Albania not only among the three rival neighboring countries but also among the three main powers of the Conference.

\section{THE USA POSITION}

The USA, Great Britain and France did not have the same attitude for the political and territorial future of Albanian state. Discussion at the Conference demonstrated that they had agreements and contradictions as well. Initially, because of not having a good knowledge about the Balkan issues, Washington accepted the view of London and Paris, according to which the independence of Albania and territorial integrity of the Albanian state would be sacrificed for the interests of neighboring countries, winners of World War I, though Albania 
had been neutral to the war and normally did not have to pay for it. In order to justify this attitude, representatives of the European big powers evaluated the international recognition of Albania in 1913 as an independent and sovereign state as a premature action (FRUS 1942, 59). The intentional, large and deafening propaganda that considered the economic-social life of Albanian people primitive, especially the one that came from neighboring countries had undoubtedly influenced the representatives of European politics.

Consequently, it was decided that Albania should be included in the system of mandates, established at the end of the world war for the countries and peoples that had not yet won their independence and would need to be under the tutelage of a 'civilized power' to lead them towards independence. In this way, Albanians were unjustly included in the group of people that would detach from the dissolved multinational states, as Ottoman Empire and Austro-Hungary, peoples that were colonized by defeated Germany.

The three big powers to the Conference also came to a common opinion that this power should be Italy, which had required since the war the protectorate form. It would demand the control over Albania in the form of mandate over Albania even during the Peace Conference. Representatives of the three powers manifested for the first time their readiness to place the post-war Albanian state under the mandate of Italy in May 1919, in the framework of efforts to satisfy claims in Albania and in the Adriatic and they were repeated in September 1919, after the request for the mandate submitted officially at the end of August by the new Foreign Minister of Italy T. Tittoni (DDI 1952, 170).

W. Wilson confirmed to his colleagues of Great Britain and France, LI. George and G. Clemenceau on 6 May 1919 that "Albanians are terrified by and despite the idea of subjugation to Italy", however he agreed with their views. Having left Paris at the end of June 1919, though he recommended to R. Lasing, his Secretary of Foreign Affairs to take care about the 'fate of Albania' and 'her rights' he accepted in the middle of September 1919 the issue of mandate of Italy over this country, Albania. However, W. Wilson took care to set conditions to it so that "exploitation or colonization" of Albania could be avoided (FRUS 1942, 345). The decision of American diplomacy to give the mandate to Italy was naturally dictated be the aim to iron out Italian-SCS contradiction on one side, but as it seems also by oscillations and indetermination of Albanian delegation in Paris.

The three big powers submitted their approval to recognize Italy's mandate over Albania in the Memorandum of 9 December 1919 that they submitted also to the Italian delegation in the Conference. The Memo attached to this Memorandum states that the three powers do not lack the will to recognize the independence of Albanian state, but "this state that will need the administrative advice and assistance of any of the Three Big Powers. From its geographical position and from its economic capacity, Italy is the most appropriate State to carry out this duty" (Macmillan 2006, 149).

The specific provisions of the mandate and Fundamental statute of Albanian state would be drafted by a commission composed of three members, one of which would be the representative of Rome government, one from the League of Nations and the third would be 
the representative of Albanian state. The latter would be appointed not by Albania, by its institutions, but by the main winning powers. These provisions (of mandate and Statute) would be approved by the Council of the League of Nations that was founded at the end of World War I and which the mission of preventing armed conflicts among the states and to preserve peace in the world.

The project that was drafted at the Peace Conference in 1919 for placing the post-war Albanian State under Italy's mandate violated the independence and sovereignty that it won some years ago. Besides, the Albanians were treated in a discriminatory way. They did not respect for it even the procedure that Covenant of the League of Nations provided for. Albanian people were not asked to give their opinion with regard to the state to which the mandate would be commissioned as provided for by Article 22 of the Covenant. These attitudes disregarded also the statements of Albanian delegation in the Conference which opposed the inclusion of Albanian in the group of countries over which the system of mandates would be applied. Representatives of the three powers of the Conference agreed not only upon Albania's independence violation but also on the other more important issue, violation of territorial integrity of the Albanian state in order to favor further neighboring countries by approving some of their claims. None if these powers objected the placing of Vlora region under the sovereignty of Italy and neither the transfer of Gjirokastër region within the political borders of Greece. Because of their geo-strategic position, Vlora and Gjirokastër became a prey, the first of Italy for its control over Otranto Channel and the second of Greece to dominate the Corfu Channel (Duka 2007, 70).

Regarding the other annexationist claims of neighboring countries, the representatives of the three powers kept differentiated attitudes. The USA representatives took care not to fragment further the regions of Albanian state, whereas the representatives of Great Britain and more those of France, having deep contradictions with Italy, were inclined to narrow further the geographical space of Albanian State, on which the Italian mandate would be extended. These contradictory attitudes were noted since the beginning of the Conference, when in February 1919 the four winning Big Powers (Great Britain, France, Italy, and the USA) created the committee to review Greek claims.

The representatives of London and Paris expressed their opinion in the report that this committee submitted in March 1919 that the entire southern Albania should be transferred to Greece, whereas Americans came out with a proposal that only Gjirokastër region would be transferred to Greece from the mountain of Nemërçkë down to the seaside, whereas the Korça region should remain within the border of Albania. Worried by the fact that their claims were not yet reviewed, but also coveting Albania with no partners, Italians pronounced for preservation of borders of 1913 in the south. As a consequence of these contradictions, the issue of Albanian-Greek border remained open (Puto 2009, 45). The Conference work started with the review of the Peace Treaty with Germany (to be signed in Versailles, near Paris, on 28 June 1919) (Macmillan 2006, 54). The three main powers were interested in this, Great Britain, France and USA. Claims of Italy over Albania started to be discussed in April 1919, 
together with her demands for lands of former Austro-Hungarian Empire, which lay mainly along the Adriatic coast. The merge of these two issues was not random, it related to London Treaty of April 1915 (with Articles 4-7), according to which the Adriatic Sea from the north to its south was conceived from the military-maritime point of view as one whole, an Italian lake which should serve for Italy's strategic 'defense'. Consequently the eastern coast sea, from Vlora in the south up to Dalmatia and Trieste in the north, was demanded to be placed under Italian control, regardless of whether it was inhabited by Albanian and Slav people, that is, non-Italians.

Faced before such claims that violated the ethnic principle, the USA representatives, free of London Treaty obligation, came against the annexationist claims of Rome government over those territories. However, they accepted in the meantime the concept of Italy's 'security' in the Adriatic and based on this, they accepted the territorial extension of Italy to some strategic positions along the coast. So, in the memorandum of 14 April 1919 addressed to the Italian government, American President Wilson accepted the Italian possession of Polas in the north, an island in the central part (in Dalmatian coast) and possession of Vlora in the south of Adriatic, considering them sufficient for control of this sea by Italy (DDI 1954, 456). The attention that American delegation and specifically the President W. Wilson paid to Albanian question by reviewing also the territorial demands of Albanian party, pronouncements of the delegation head in some cases to the benefit of Albanians, testify that USA, or the American diplomacy was the only among decision makers of the Peace Conference that was concerned in some way that the territories given to Albania in 1913 remain (Macmillan 2006, 160). The USA attitude could be noticed in the Memorandum of 9 December 1919 and openly in February-March of 1920, in the period after the Conference, when W. Wilson opposed strongly the English-French-Italian plan of 13-14 January of that year, which in essence implemented London Secret Treaty of 1915 that fragmented Albania badly and nullified its independence. The Memorandum of 9 December came as a need for the coordination of the attitude for questionable issues among representatives of USA, Great Britain and France.

In this Memorandum they submitted the same opinions for the 'Adriatic issue' Resolution, and their views regarding the claims of the three neighboring states in Albania, of Italy and the two Balkan states. The drafting of the 9 December document is actually considered more as a view of the American representatives. Pursuant to it, full sovereignty over Vlora and its entire region was recognized for Italy, Kingdom of Serbs, Croats and Slovenes was allowed only the right of the commercial exit in the northern Albania by leaving thus unaffected the borders of 1913, whereas no common opinion was reached about Albanian-Greek border. However, according to the Memorandum of 9 December, Greece would invade Albanian lands of Gjirokastër region that lay in the west of Nermërçkë Mountains, including Tepelenë and Kurvelesh. The invasion of Gjirokastër region was only one step towards its annexation by Greece. The future of Korça remained again subject to negotiations among representatives of USA, France and Great Britain on one hand, which 
possessed the right to speak on behalf of Albania, and representatives if Italy and Greece on the other hand (FRUS 1942, 345). Meanwhile, this Memorandum did not satisfy Rome, because of the Resolution given to Fiume issue, neither Athens for the reservation held towards the future of Korça. It infuriated more Belgrade that saw it excluded from division of Albania and in military difficult defensive positions related to Italy. According to the Kingdom of Serbs, Croats and Slovenes delegation, the powers were interested only in the 'strategic security' in the Adriatic. In these conditions, Belgrade delegation, headed by N. Pasic, in the note sent to the Conference on 8 January 1920, defended again the attitude expressed in February 1919, according to which his government preferred the establishment in the borders of 1913. The note of N. Pasic stressed also that if the proposal would be rejected again, Belgrade would demand the annexation of northern Albania down river to Drin River, promising in this case to give a local administrative autonomy to Shkoder. The Kingdom of SCS delegation demanded now a 'more favorable' border for Belgrade, from the economic and strategic point of view. In this case there was no mention of 'correction of borders', as the Kingdom of SCS memorandum of 8 January stated, but annexation of all territories on the right side of Black Drin and Buna Rivers, and mountains of Kelmend and Krasniq.

To satisfy further the neighbors of Albania, especially the Kingdom of Serbia, Croats and Slovenes, the Prime minister of Great Britain and France, D. Lloyd George and G. Clemenceau, in the absence of USA representatives, reached a compromise on 13 January 1920 with the Italian counterpart, Nitti, according to which Albania would be divided among the three neighboring countries, almost in the same way as London Treaty of 1915 provided for. According to this compromise, Fiume would be transferred to Italy, whereas the Kingdom of Serbia, Croats and Slovenes would receive as compensation the northern Albania with the center in Shkoder, which would enjoy 'the autonomy' like that of Rutene region in Czechoslovakia.

Greece would annex Korça and Gjirokastër, whereas Italy would be given the sovereignty over Vlora and its region, and the mandate over the remaining part of Albanian state of 1913. The USA intervention to oppose the British-French-Italian plan saved Albanian state. The determined attitude of the USA President W. Wilson, regardless of problems with the political opponents in Washington and his health situation, gave time to Albanians to organize the resistance that started in Lushnje Congress, which did not accept the Italian mandate and rejected any further foreign mandate. After this, resistance would continue with Vlora War, in order to regain the sovereignty if Albania over this region. In this way, regarding Albania and the Albanian Question, Peace Conference of 1919-1920 sanctioned not only the unjust decision of the Conference of Ambassadors if 1913, but it designed also a new division of Albanian state territories. The Albanian representatives reacted against those injustices, but again with no outcome. 


\section{THE ATTITUDE OF ALBANIAN DELEGATION}

The disregarding attitude of the Peace Conference for national rights of the Albanian people and neglect of the proposal that Albanian delegation submitted to this Conference on 7 March 1919 for the organization of a plebiscite in Albanian territories that were left outside the borders of Albanian state, urged this delegation to look for other political means in order to save the country from the risk of a new division. But delegation members did not reach a common opinion about the further steps that they should make. A part of it, composed of Memhet Konica and Dr. Mihal Turtulli, joined also by Mithat Frasheri (who was still in Switzerland), though that a strong critical attitude should be kept against the claims of Italy, in which they saw the main source of that new drama that was being prepared for Albania (Macmillan 2006, 159). They thought that they would change with this critical attitude against Italy the image crated for the delegation, to prove that it was not an annex to Rome representatives as it was spoken among diplomatic circles, but they had gone to Paris to protect the national rights of Albanians and to oppose those who violated these rights.

There were also many delegates, member of the Albanian colony in USA, Turkey and Romania that were against Italian demands over Albania. Among them were Mihal Grameno, Parashqevi Qiriazi, Halil Pasha Alizoti (Gjirokastra), Fuat Dibra, Pandeli Evangjeli, Ibrahim Temo. The other part of the delegation composed of Turhan Pasha Pwrmeti, father Luigh Bumci, and Luigj Gurakuqi (the latter was appointed instead of Mithat Frashëri), though that they should follow the way of non-confrontation and non-exacerbations to achieve a compromise with them which would be based on respect of independence and preservation of territorial integrity of the country. These contradictions led to the creation of two separate groups of governmental delegation. Their separate actions started in April 1919, when news spread for the start of 'Adriatic issue' discussion at the Conference. So, fractions sent to the Peace conference one Memorandum each on the same day, on 14 April. In the Memorandum submitted to the Conference, the fraction of Konica-Turtulli, which held the American-English orientation, used a very strong tone against the aim of Italy on Vlora ant it highlighted the negative consequences that Italian protectorate would have for Albania first of all from the demographic point of view. In this memorandum was stressed the dangerous Italian attitude to colonize Albania (Puto 2009, 103). However, the members of this group did not come before the Conference with their proposal to recognize the complete independence of Albanian state and, starting from this demand they objected the plans of representatives of big powers to place it under the mandate of a foreign state. Knowing the internal issue that existed in Albania and trying to stabilize the Albanian state and to avoid the Italian mandate, they required the placing of the Albanian independent state under the temporary mandate of the USA, or some other distant power, that 'did not have' direct interest in Albania and the Balkans as well. In the 14 April's Memorandum, the other fraction, with the pro-Italian orientation, demanded for a certain time until Albanian state would recover not the establishment of the mandate system, but the 'assistance' system, stressing 
the 'benevolent assistance', of one of the big powers that the Albanian government would chose. This power, as the Memorandum implied, would be Italy, the 'assistance' of which would be such that it should be compliant with the Albanian independence and sovereignty and it should not be used by Rome to colonize the country. The proposal of this fraction shows that it tried to avoid the mandate over Albania. But, as Memorandum of April 1919 demonstrates, all Albanian delegates in Paris accepted the transfer of Albanian state by one single power. The group of Turhan Pasha, joined by Mustafa Kruja and later by two other government members, Mehdi Frasheri and Mufit Liboohva (who arrived in Paris at the end of April), made efforts to reach a bilateral agreement with Rome Government. In order to avoid the sovereignty over Vlora Region, they decided to recognize the 'strategic and maritime' interests of Italy in this region by accepting, it Italy would guarantee the territorial integrity of Albanian State, the military invasion of Sazan, Karaburun and Zvwrnec, and the construction of a maritime military base in Pashaliman. These cessions were proposed to the Italian part on 28 May 1919, but their authors received no reply for it. However, after one full month, on 28 June, the group of Turhan Pasha made changes in the delegation composition. The delegation head was appointed father Luigj Bumbi instead of Turhan Pasha. Avoidance of Turhan Pasha, who was once an Ottoman Empire ambassador, as it seems, related to the purpose to change somewhat the image ascribed malevolently to Albania by foreign propaganda as the 'small Turkey'. The delegation members would be Mehdi Frasheri, Luigh Gurakuqi and Lef Nosi. However, Turhan Pasha remained again as prime minister, whereas Mehdi Frasheri was appointed as Foreign Minister instead of Mehmet Konica. These changes were made by the 6 government members that were in Paris, who acted in the name of the other cabinet members that were in Durres. On the same day, on 28 June in the meeting of the 6 government members, stresses that the delegation headed by L. Bumci would continue to fulfill its activity, on the principle of Albanian state territorial integrity, independence and sovereignty" (History of Albania 2005, 289). After one month, in July, some unexpected event happened that alarmed Albanian political circles and the Albanian public opinion. The new Italian Minister of Foreign Affairs, Tomasso Tittoni, signed an agreement with the Greek prime minister, E. Venizelos on 29 July 1919 for settling their contradiction (including those for division of Albania) and to support the claims of each other before the Peace Conference. This aggravation of international situation for Albania had a profound impact on Albanian representatives in Paris. At the end of July, Turtulli-Konica fraction joined the other part of Albanian delegation, from which it had detached since April. In this case, M. Konica was accepted to remain a delegation member, whereas, Dr. M. Turtuli would be lowered to the level of advisor delegate. The representatives of colonies in Paris made the same step in those days; they decided to cooperate with the delegation headed by L. Bumci. Meanwhile, the news was spread in September 1919 for acceptance of Italian mandate over Albania by the powers caused a new debate among Albanians in the French capital for the method of objecting this Conference approval. Most of the representatives of colonies required from the governmental delegation to come before the Peace Conference with the demand for an 
entirely independent state as the only diplomatic means to avoid the mandate. But willing to guarantee necessarily to Albanian state 'a benevolent and temporary assistance', this delegation came out with another proposal. In its Note addressed to the Conference on 9 October, the governmental delegation stressed that this 'assistance' could be given to Albania without establishing the mandate institution, but "through a reasonable change and in accordance with the spirit of the time and the needs of the country, with provisions of London Conference of 1913 on establishment of the Albanian state" (History of Albania 2005, 290). According to the delegation, there were two changes that should be made in the status of 29 July: First, a foreign Prince should become the head of Albanian state as in 1913, with the difference that the Prince now should be of Italian origin (from Savoia Royal House) and accompanied by foreign armed forces (which did not happen in 1913), which should be Italian and will stay in Albania temporarily until Albanian state would be stabilized. They would be as escorting or accompanying forces to the prince and not as invaders of the country. The second change concerned Albanian's neutrality. This neutrality should be restored and 'guaranteed' collectively by the powers as in 1913, with the difference that, if necessary, these powers would commission Italian government "to implement the guarantee condition" (AQSH 1919, 12). The 9 October's Note addressed to the Conference was associated by the delegation request to be summoned by the Conference to hear its views about the issue related to the future of Albania. This request had been repeated several times but it had not been accepted. It was only in February 1919 that Albanian delegation was summoned and heard for the first time by the Council of the Ten in the Conference. The Albanian delegation communicated with the Conference only by correspondence. In these conditions of discrimination by this international forum, when the Italian party was silent about Albanian delegation proposals and it was not showing any availability for compromise, the delegation made another step. The delegation presented to the Peace Conference a new Note with several proposals at the end of December 1919 intending to avoid the partition of the country. This delegation accepted to recognize some cession to the neighbors: Kingdom of Serbs, Croats and Slovenes, the free transit of goods in northern Albania; 'internal autonomy' of Orthodox communities of Korçë and Gjirokastër; for the 'security' of Italy in the southern Adriatic, it stated that it was ready to submit to the Conference such a variant that preserved the sovereignty of Albania over Vlora and over its region. In this case, they thought that Italy should be allowed to build a 'rented' military maritime base in Orik (Pashaliman) and recognition of Sazan island invasion. But, as previously, these proposals fell on deaf ears. Finding no support in the Conference, Albanian delegation sent two of its members to Rome at the end of 1919 to require the help of Pope. The delegation headed, the Catholic clergy, father Luigj Bumci met the Pope in January 1920 without reaching any conclusion resistance so as to prevent with it the achievement of an unfavorable equilibrium for Albania in the negotiations between big powers. The foundations for organization of this resistance were laid in Lushnje Congress (Duka 2006, 230). The Congress decided to de facto independence for Albania. 


\section{CONCLUSION}

It can be concluded that the USA was the major player of that time. Albania was recognized as an independent state. The world learned that even in very difficult and crucial circumstances, Albanians demonstrated their readiness and determination to protect the independence of their national state. They appeared as a factor that should be necessarily taken into consideration after this. Following the USA, by the end of 1920, Great Britain too would make diplomatic movements in favor of Albania. Facing London pressure, Rome withdrew from its attitude to prevent admission of Albania to the League of Nations on 5 December. Albania became a member of this organization on 17 December. After this, the efforts of Italian diplomacy would focus on prevention of Kingdom of Serbs, Croats and Slovenes, and Greek intentions towards the Albanian state in order to guarantee a privileged political and economic position of Italy in Albania. With the statement of 9 November 1921, signed together with France, Great Britain and Japan, Italy guaranteed the first, but, facing British opposition, it did not achieve for the second time. 


\section{REFERENCES}

1. Albanian Center Archives (AQSH)

2. Archivio dello Stato Maggiore del Esercito Uffifcio Storico (ASME US) Roma

3. Archivio Storico e Diplomatico di Ministero degli Affari Esteri Italiano (ASDMALE) Roma

4. Albania Institute Archive, (AlH), Albania

5. Aldovrandi, L. 1940. La guerra diplomatica. Ricordi e fragmmenti di diario 1914-1919. Verona: Casa Editrice A. Mondadori.

6. Carapanos, Alexandros- Memorandum sur l'Epire du Nord, 1919.

7. Collona di Cesario, G.A. 1922 L'Italia nell Albania Meridionale. Note e documenti (19171918), Roma: Foligno.

8. Clogg, Richard. 2004 A brief History of Greece. Tiranë: Toena.

9. Della Rocca, Roberto. 1994 Kombësia dhe feja në Shqipëri 1920-1944. Tiranë: Elena Gjika.

10. Dibra, Pranvera. 2005 Shqipëria dhe Diplomacia Angleze. Tiranë: Neriada publisher.

11. Duka, Valentina. 2007 Historia e Shqipërisë 1912-2000. Tiranë: Kristalin-KH.

12. Fischer, Bernd. 2004 Mbreti Zog dhe përpjekja për stabilitet në Shqipëri. Tiranë: Çabej Publisher.

13. Documenti Diplomatici Italiani (DDI). 1954-1980. Quinta serie, 1914-1918; vol. I,IV,VII,VIII; Sesta serie, 1918-1922, vol.I, II (Roma: ISTITUTO POLIGRAFICO DELLO STATO.

14. Papers relating to the Foreign Relations of United States (PRFRUS) 1919. 1942 The Paris Peace Conference, Vol. I, III., Washington: United States Government Printing Office

15. Sonnino, Sidney. 1922 Discorsi per la Guerra. Roma: Foligno Campitelli

16. Robert L. Jarman. 1997 Yugoslavia. Political Diaries (1918-1965), vol. I (1918-1926). London: Archive Editions Ltd; Archive Ed edition

17. Montanelli, Indro. 2005 Shqipëria një dhe njëmijë. Tiranë: "55" Publisher.

18. Puto, Arben.2009 Shqipëria Politike 1912-1939. Tiranë: Toena.

19. Zavalani, Tajar. 1966 Historia e Shqipërisë. London: Cambrige Edition. 